\title{
PIELGRZYM DO ZIEMI ŚWIĘTEJ
}

Wśród różnych wydarzeń życia i działalności Kardynała Karola Wojtyły nie powinien ujść uwagi drobny na pozór fakt odbycia przez Metropolitę Krakowskiego pielgrzymki do Ziemi Swiętej. Że nie był to tylko jakiś epizod $w$ jego życiu, świadczy list $\mathrm{z}$ dnia 10 stycznia 1964 r., podpisany przez niego jako jeszcze przez biskupa wikariusza kapitulnego Archidiecezji Krakowskiej, a skierowany do wszystkich kapłanów Archidiecezji i informujący o odbyciu pielgrzymki oraz opisujący zwiedzane miejsca (por. Notificationes e Curia Metropolitana Cracoviensi n. 3-4 (1964) 66-74). Biskup Karol Wojtyła po zakończeniu II sesji Soboru Watykańskiego II, w dniach 5-15 grudnia 1963 r., odbył wraz z kilkunastu biskupami polskimi pielgrzymkę do Ziemi Swiętej.

O motywach tej pielgrzymki pisze we wstępie listu: „...po zakończeniu drugiej sesji Soboru miałem szczęście wraz z kilkudziesięciu innymi Biskupami z różnych narodów uczestniczyć w pielgrzymce do Ziemi Świętej. Już w roku ubiegłym Ojczyzna Odkupiciela przyciągała do siebie wielu Ojców Soboru. W roku bieżącym stało się to jeszcze bardziej powszechne. Czujemy, że pracując ną odnową Kościoła na Soborze, musimy zwrócić się wprost do samego Chrystusa Pana, którego Kościól jest Ciałem Mistycznym. I stąd pragnienie nawiedzenia tych miejsc, gdzie On narodził się, żył, nauczał i działał, wreszcie cierpiał, umarł na krzyżu, zmartwychwstał i wniebowstąpił. Pragnieniu temu dał wyraz w dniu zakończenia drugiej sesji Soboru 4 grudnia sam Ojciec Swięty Pawel VI, zapowiadając, że i on w najbliższym miesiącu uda się w pielgrzymce do Ojczyzny Chrystusa Pana. Zapowiedź ta urzeczywistniła się w tych dniach".

Istotnie, Papież Paweł VI odbył pamiętną pielgrzymkę do Miejsc Swiętych w dniach 4-6 stycznia 1964 r.

„Pielgrzymka Ojca św. - pisze dalej w swym liście wikariusz kapitulny krakowski - nadała niejako wyższą jeszcze rangę pielgrzymkom Ojców Soboru do Ziemi Swiętej, a między innymi także i tej, w której miałem szczęście brać udział (...) Udziału tego nie traktowałem jako osobistej tylko czy też prywatnej własności, ale jako łaskę daną mi przez Opatrzność również dla drugich. I dlatego wkrótce po powrocie z sesji Soboru oraz z Ziemi Swiętej pragnę podzielić się przede wszystkim z Wami, Drodzy Bracia 
w kapłaństwie, bliskimi jeszcze wspomnieniami z tej pielgrzymki. (...) W każdym razie pragnę, aby oczy Wasze choć za pośrednictwem tego listu spojrzały na to, na co mnie dane było patrzeć życzę Wam zaś, abyście kiedyś mogli spojrzeć na to własnymi oczyma. Przyczynia się to bowiem bardzo do ożywienia wiary".

Biskup Wojtyła przechodzi w swym liście według chronologii życia Jezusa zwiedzane miejsca; w zwięzłości opisu uderza wielki zmysł obserwacji i umiejętność ujęcia najważniejszych rzeczy. Nie brak przy tym drobnych szczegółów, które tak bardzo potrafią dodać kolorytu wszelkim narracjom. Miłośnik kolęd (kto słyszał kardynała Wojtyłę śpiewającego kolędy, nie zapomni tego długo) nie zrezygnował z odnotowania choćby takiego szczegółu: „w grocie Bożego Narodzenia Biskupi polscy nie omieszkali odśpiewać kilku kolęd, do czego zobowiązał ich staruszek o. Borkowski franciszkanin polski od dziesiątków lat pracujący $w$ Ziemi Swiętej".

Spośród wielu opisów miejsc świętych warto zwrócić uwagę na dwa miejsca, co zresztą sam Autor podkreśla pod koniec swego listu:

„Jedno to Joppa z kościołem św. Piotra, który tutaj w Joppie doznał dziwnego widzenia i stąd poszedł ochrzcić Korneliusza. Wypada dodać, że w kościele w Joppie jest oltarz Matki Boskiej Częstochowskiej, a miejscowy franciszkanin, Polak, mówi kazania w naszym języku, bo większość wiernych ten przede wszystkim język rozumie. Drugie miejsce, które pragnę wspomnieć, to Areopag w Atenach. Miejsce opodal Akropolu $z$ jego wspaniałymi świątyniami, w którym św. Paweł przemawiał do Ateńczyków o Bogu nieznanym. Oba te miejsca, które wspominam, wprowadzają nas ze światem Ewangelii w świat Dziejów Apostolskich, w początki historii Kościoła".

A oto konkluzja z pielgrzymki:

„Drodzy Księża! Na dzisiejszym dalekim etapie tego Kościoła, w okresie II Soboru Watykańskiego, te wszystkie święte miejsca mówią do nas wciąż tą samą prawdą - prawdą Odkupienia świata".

Czy tej prawdy nie odczytujemy w Encyklice Jana Pawła II Redemptor hominis?

Ks. JERZY CHMIEL 